\title{
EFFECT OF SOME NATURAL MATERIALS ON in vitro MICROPROPAGATION Of "NAVEL ORANGE "
}

(Received: 1.7. 2010)

\author{
By \\ R. A. Anwar, A. H. Gomaa*, M. H. Abd El-Zaher* and S. B. El- Harouny \\ Citrus Department, Horticulture Research Institute, Agricultural Research Center, Giza, Egypt. \\ *Pomology Department, Faculty of Agriculture, Cairo University, Giza, Egypt.
}

\begin{abstract}
The main goal of this work was studying the effects of adding some natural materials to the culture media instead of the growth regulators on the growth of navel orange plantlets . Natural materials with variant concentrations were used (coconut milk, jojoba oil, orange juice and two types of humic acid viz., powder and liquid. Explants cultured on MS medium supplemented with 15\% orange juice showed the highest percentage of contamination $(74.10 \%)$, while explants cultured on medium with $250 \mathrm{mg} / \mathrm{l}$ humic acid (powder) showed the lowest percentage of contamination $(7.40 \%)$. Explants cultured on medium with $1 \%, 3 \%$ or $6 \%$ jojoba oil and the control (1) medium (MS basal medium with $2 \mathrm{mg} / \mathrm{l} \mathrm{BAP+}$ $1 \mathrm{mg} / \mathrm{l}$ kinetin $+1 \mathrm{mg} / \mathrm{l} \mathrm{NAA}$ ) did not show any contamination.

Explants cultured on a medium with $0.25 \mathrm{ppm}$ humic acid (liquid), medium with $250 \mathrm{mg} / \mathrm{l}$ humic acid (powder), medium with 5\% coconut milk; and the control (1) medium showed the highest percentage of sprouting $(87.50,83.80,83.30$ and $85.20 \%$, respectively) while, all explants cultured on medium with $750 \mathrm{mg} / \mathrm{l}$ humic acid ( powder ) or medium with $0.75 \mathrm{ppm}$ humic acid (liquid ) failed to sprout (zero \% ). Sprouting explants cultured on medium with $10 \%$ orange juice, medium with 5 or $10 \%$ coconut milk and medium with $0.25 \mathrm{ppm}$ humic acid (liquid )resulted in the highest shoot number / explant ( 6.92 , 6.52, 6.07 and 5.90 shoots / explant, respectively). Explants cultured on medium with $750 \mathrm{mg} / \mathrm{l} \mathrm{humic}$ acid (powder) or $0.75 \mathrm{ppm}$ humic acid (liquid) failed to produce any shoots . Sprouting explants cultured on a medium with $10 \%$ orange juice or control (1) medium showed the highest shoot length ( 1.60 and $1.57 \mathrm{~cm}$, respectively) and the highest leaves number (4.73 and 5.40 leaves/shoot, respectively).In vitro shoot explants cultured on rooting medium with $750 \mathrm{mg} / \mathrm{l}$ humic acid (powder) produced the highest number of roots/shoot ( 7.93 roots/shoot) followed significantly by 7.00 roots/shoot rooting medium with $500 \mathrm{mg} / \mathrm{l}$ humic acid (powder), while in vitro shoot explants cultured on rooting medium with $5 \%$ coconut milk, $250 \mathrm{mg} / \mathrm{l} \mathrm{humic} \mathrm{acid} \mathrm{(powder)} \mathrm{,} \mathrm{10 \%} \mathrm{orange} \mathrm{juice} \mathrm{,} \mathrm{control(1)} \mathrm{medium} \mathrm{,} \mathrm{0.5ppm} \mathrm{humic} \mathrm{acid}$ (liquid) and 500mg/l humic acid (powder) produced the longest roots $(1.60,1.53,1.50,1.50,1.43$ and $1.40 \mathrm{~cm}$, respectively).
\end{abstract}

Key words: culture media, micropropagation, natural materials, navel orange.

\section{INTRODUCTION}

Orange is considered the first citrus crop in Egypt, in respect to the exporting, as $61 \%$ of the total citrus production in Egypt (Agriculture Statistics , 2007 , Ministry of Agriculture , Egypt ) Micropropagation is an important asexual method that can be used for producing virus-free plants (Roistacher et al., 1976). Tissue culture and micropropagation protocols have been described for a number of citrus species and explant sources (Barlass and Skene ,1982). In vitro plant regeneration of citrus species has been demonstrated through somatic embryogenesis (Vardi et al., 1982; De Pasquale et al., 1994 ) and organogenesis (Moore,1986; Sauton et al.,1982;) and Barlass and Skene, 1982 from various citrus explants .One of the major problems of in vitro plant cultivation is the high level of somacolnal variation, that may be due to an interaction between the explant, the growth regulators and long periods of subculture (Corneanu et al., 2002) .Several experiments were carried out to develop protocols for the in vitro propagation of citrus using several explants . Murashige and Skoog 1969 (MS) medium supplemented with various concentrations of natural materials has been used to determine the rate of shoot proliferation and rooting (Einest, 1978). 
The objective of this study was to develop a tissue culture protocol for navel oranges using nodal explants from mature trees to explore the effect of adding some natural materials in the culture media i.e., jojoba oil , coconut milk, humic acid and orange juice instead of the growth regulators on micropropagation of navel oranges for avoiding somaclonal variation .

\section{MATERIALS AND METHODS}

This work was carried out at the Tissue Culture Laboratory, Horticulture Research Institute , Agricultural Research Center, Giza, Egypt . The experiment was carried out during the period of 2006 to 2009 ,to investigate the effect of some natural components added to MS media on the rate of growth ( shooting and rooting ), which replaced growth regulators. The additions used included the natural components coconut milk, humic acid (liquid and powder), orange juice and jojoba oil .

\subsection{Preparation of explants}

Actively growing new shoot $(10 \mathrm{~cm}$ long ) were taken from mature trees, about 10 year old of navel orange grown in the orchard of the Horticulture Research Institute, Giza, at the beginning of March . The collected shoots were washed carefully under running tap water for one hour, and then sterilized in 70\% ethanol for 3-5 min. , followed by $2 \%(\mathrm{w} / \mathrm{v})$, sodium hypochlorite for $15 \mathrm{~min}$. containing one drop of Tween-20, and then rinsed three times in sterile distilled water for $4 \mathrm{~min}$. for each one. Sterilization was carried out according to the procedure reported by Al-Kayri and Al-Baharany (1982) and Al- Baharany (2002). Sterilized shoots were stripped of their leaves and then cut into segments $(1 \mathrm{~cm}$ long) and each segment contained one lateral bud .

\subsection{Basal medium composition}

Throughout the study, MS basal medium (Murashige and Skoog,1962) was used .The media were solidified with 7-8 g/l agar and supplemented with sucrose at $30 \mathrm{~g} / \mathrm{l}$. The $\mathrm{pH}$ of the medium was adjusted to 5.8 with $0.5 \mathrm{M}$ potassium hydroxide $(\mathrm{KOH})$, dispensed in $250 \mathrm{ml}$ jar, each jar contained $30 \mathrm{ml}$ of the culture medium . The culture jars were sealed with caps of polyvinyl propylene, and autoclaved at $121{ }^{\circ} \mathrm{C}$ for 20 minutes .

The natural materials were used as substitutes for the growth regulators according to the experimental stages as mentioned below . Natural materials were sterilized by the filtration throughout the special sterilized microbial filters .
To examine the response of node explants to natural additions and growth regulators, the sterilized node explants were cultured on media supplemented with the following concentrations of the studied materials :-

1.Jojoba oil $(1 \%, 3 \%$ and $6 \%)$,

2.Coconut milk(2.5\%,5\% and $10 \%)$,

3. Orange juice $(5 \%$ and $10 \% 15 \%$ )

4. Two types of humic acid (actosol $($ ) ) as mentioned in Table (1)

- powder $(250 \mathrm{mg} / 1,500 \mathrm{mg} / \mathrm{l}$, and 750mg/l)

- $\operatorname{liquid}(0.25 \mathrm{ppm}, 0.5 \mathrm{ppm}$ and $0.75 \mathrm{ppm})$

Table (1): Main characteristic of actosol $®$ used in the investigation.

\begin{tabular}{|l|c|c|c|}
\hline Components & Value & Components & Value \\
\hline Humic acid (\%) & 2.9 & $\mathrm{P}(\%)$ & 10.00 \\
\hline $\begin{array}{l}\text { Organic } \\
\text { matter/total }\end{array}$ & 42.51 & $\mathrm{~K}(\%)$ & 10.00 \\
\hline $\begin{array}{l}\text { Total HA/total } \\
\text { solid }\end{array}$ & 165.80 & $\mathrm{Ca}(\%)$ & 0.06 \\
\hline $\begin{array}{l}\text { Organic carbon } \\
(\%)\end{array}$ & 24.64 & $\mathrm{Mg}(\%)$ & 0.05 \\
\hline $\mathrm{C} / \mathrm{N}$ ratio & 2.46 & $\mathrm{~B}(\mathrm{mg} / \mathrm{l})$. & 70.00 \\
\hline $\mathrm{pH}$ & 8.10 & $\mathrm{Fe}(\mathrm{mg} / \mathrm{l})$. & 900.00 \\
\hline
\end{tabular}

Different treatments were compared with control (1) medium (MS basal medium with the additions of 2mg/l 6-benzylaminopurine (BAP), $1 \mathrm{mg} / \mathrm{l}$ kinetin and $1 \mathrm{mg} / \mathrm{l}$ 1-naphthaleneacetic acid (NAA)) and control (2) medium (MS basal medium without any additions of growth regulators or natural additions).

Nine explants were cultured per treatment (three jars / replicate and three replicates / treatment ). Cultures were incubated at $24 \pm 2{ }^{\circ} \mathrm{C}$ under $16 \mathrm{~h}$ photo period of cool- white fluorescent light. The cultured explants of each treatment were subcultured on fresh medium at four-week intervals. Data were recorded at the end of the second subculture including percentages of contamination, sprouting (\%) ,number of shoot , shoot length $(\mathrm{cm})$ and leaf number .

\subsection{Rooting medium}

In vitro shoots were separated from shoot cluster and cultured on rooting media which consist of MS basal medium without any additions of growth regulators to test the effect of natural additions on root development. Rooting media had the same concentrations of natural additions and under the same light and temperature regime used for shoot multiplication. Resulting data were compared with control (1) medium which consists of MS basal medium with the addition of $1 \mathrm{mg} / \mathrm{l}$ (NAA) and control (2) medium, which consists of 
MS basal medium without any additions of growth regulators or natural additions . Data were recorded as rooting percentage, root number and length of $\operatorname{root}(\mathrm{cm})$.

\subsection{Statistical analysis}

Data of shoot multiplication and rooting were subjected to analysis of variance (ANOVA) and means were separated where appropriate, using the least significant difference (LSD) at 5\% significant as described by Snedecor and Cochran (1980).

\subsection{Contamination}

\section{RESULTS}

The data in Table(2) refer to the effect of different concentrations of coconut milk, humic acid(powder and liquid), orange juice and jojoba oil on contamination percentage . Data revealed that adding $15 \%$ orange juice to the MS basal medium resulted in the highest percentage of contamination $(74.10 \%)$ followed by the contamination percentage $(51.87 \%)$ of explants cultured on medium supplemented with $10 \%$ orange juice. Explants cultured on medium with $250 \mathrm{mg} / \mathrm{l}$ humic acid (powder) showed the lowest percentage of contamination $(7.40 \%)$. All the explants cultured on media with $1 \%, 3 \%$ or
$6 \%$ jojoba oil and control (1) medium (MS basal medium with $2 \mathrm{mg} / \mathrm{l} \mathrm{BAP}+1 \mathrm{mg} / \mathrm{l}$ kinetin $+1 \mathrm{mg} / \mathrm{l}$ NAA) did not show any contamination .The contamination percentages of the other treatments were in between.

\subsection{Sprouting}

The data in Table (3) show the effect of treatments on sprouting percentage, data revealed that the explants cultured on a medium with humic acid (liquid) at $0.25 \mathrm{ppm}$, medium with $2 \mathrm{mg} / \mathrm{l} \mathrm{BAP}+1 \mathrm{mg} / \mathrm{l}$ kinetin $+1 \mathrm{mg} / \mathrm{l}$ NAA control (1), medium with humic acid (powder) at 250 $\mathrm{mg} / \mathrm{l}$ and medium with coconut milk at 5\% resulted in the highest significant sprouting percentage $(87.50,85.20,83.80$ and $83.30 \%$ respectively) without significant differences between them. These percentages are followed significantly by the sprouting percentage $(76.67 \%)$ of explants cultured on MS basal medium supplemented by orange juice at $10 \%$. On the other hand, all explants cultured on MS basal medium supplemented with humic acid (powder) at $750 \mathrm{mg} / \mathrm{l}$ or humic acid (liquid ) at $0.75 \mathrm{ppm}$ failed to sprout as the sprouting percentage was zero. The sprouting percentage of the other treatments were in between .

Table (2):Effect of coconut milk, humic acid, orange juice and jojoba oil on contamination percentage of navel orange explants (After 6 to 10 days of culture).

\begin{tabular}{|l|c|c|}
\hline \multicolumn{1}{|c|}{ Treatment } & Concentration & Contamination (\%) \\
\hline \multirow{2}{*}{ Coconut milk \% } & 2.5 & $37.00 \mathrm{~d}$ \\
& 5 & $37.00 \mathrm{~d}$ \\
& 10 & $33.30 \mathrm{e}$ \\
\hline \multirow{2}{*}{ Humic acid (powder) mg/l } & 250 & $7.40 \mathrm{~h}$ \\
& 500 & $14.80 \mathrm{f}$ \\
& 750 & $14.80 \mathrm{f}$ \\
\hline \multirow{3}{*}{ Humic acid (liquid) ppm } & 0.25 & $11.10 \mathrm{~g}$ \\
& 0.5 & $7.40 \mathrm{~h}$ \\
& 0.75 & $14.80 \mathrm{f}$ \\
\hline \multirow{3}{*}{ Orange juice \% } & 5 & $40.70 \mathrm{C}$ \\
& 10 & $51.87 \mathrm{~b}$ \\
& 15 & $0.00 \mathrm{i}$ \\
\hline \multirow{2}{*}{ Jojoba oil \% } & 1 & $0.00 \mathrm{i}$ \\
& 3 & $0.00 \mathrm{i}$ \\
\hline * Control ( 1) medium & 6 & $0.00 \mathrm{i}$ \\
\hline ** Control ( 2) medium & & $7.40 \mathrm{~h}$ \\
\hline
\end{tabular}

Means designated with the same letter in the same column are not significantly different at L.S.D 0.05 level of probability

* MS basal medium with growth regulators

** MS basal medium without growth regulators 


\subsubsection{Shoot number}

The data presented in Table (4) show the effect of coconut milk, humic acid(powder and liquid), orange juice and jojoba oil on shoot number/ explant . Explants cultured on medium with orange juice at $10 \%$, medium with coconut milk at $5 \%$ or $10 \%$ and medium with humic acid (liquid) at $0.25 \mathrm{ppm}$ resulted in the highest significant number of shoots per explant $(6.92$, $6.52,6.07$ and 5.90 shoot/explant, respectively) without significant differences between them .Explants cultured on MS basal medium supplemented with humic acid (powder) at failed to produce any shoots. The shoot length of the other treatments were in between.

\subsubsection{Leaf number}

The effects of coconut milk, humic acid(powder and liquid), orange juice and jojoba oil on leaf number are shown in Table (4) .The greatest leaf formation (5.40 and4.73 leaves / shoot) was observed by adding $2 \mathrm{mg} / \mathrm{l} \mathrm{BAP}+$ $1 \mathrm{mg} / \mathrm{l}$ kinetin $+1 \mathrm{mg} / \mathrm{l} \mathrm{NAA}$ control (1) or orange juice at $10 \%$, respectively to culture medium , followed significantly by leaf number (3.67 and 3.10 leaves / shoot ) of explants cultured on medium supplemented with coconut milk at $5 \%$ or

Table (3): Effect of coconut milk, humic acid, orange juice and jojoba oil on sprouting percentage of navel orange explants (After 2 weeks of culture ).

\begin{tabular}{|c|c|c|}
\hline Treatment & Concentration & Sprouting $(\%)$ \\
\hline \multirow{3}{*}{ Coconut milk \% } & 2.5 & $24.50 \mathrm{~h}$ \\
\hline & 5 & $83.30 \mathrm{a}$ \\
\hline & 10 & $62.40 \mathrm{c}$ \\
\hline \multirow{3}{*}{ Humic acid (powder) mg/l } & 250 & $83.80 \mathrm{a}$ \\
\hline & 500 & $22.03 \mathrm{~h}$ \\
\hline & 750 & $0.00 \mathrm{j}$ \\
\hline \multirow{3}{*}{ Humic acid (liquid) ppm } & 0.25 & $87.50 \mathrm{a}$ \\
\hline & 0.5 & $24.07 \mathrm{~h}$ \\
\hline & 0.75 & $0.00 \mathrm{j}$ \\
\hline \multirow{3}{*}{ Orange juice \% } & 5 & $31.10 \mathrm{~g}$ \\
\hline & 10 & $76.67 \mathrm{~b}$ \\
\hline & 15 & $44.50 \mathrm{e}$ \\
\hline \multirow{3}{*}{ Jojoba oil \% } & 1 & $14.80 \mathrm{i}$ \\
\hline & 3 & $37.00 \mathrm{f}$ \\
\hline & 6 & $51.87 \mathrm{~d}$ \\
\hline$*$ Control ( 1) medium & & $85.20 \mathrm{a}$ \\
\hline ** Control (2) medium & & $36.10 \mathrm{f}$ \\
\hline
\end{tabular}

$750 \mathrm{mg} / \mathrm{l}$ or humic acid (liquid ) at $0.75 \mathrm{ppm}$ failed to produc any shoots. The shoot number per explant of the other treatments was in between.

\subsubsection{Shoot length}

The results in Table (4) indicate that the highest shoot length $(\mathrm{cm})$ was obtained from explants cultured on medium with orange juice at $10 \%$ or medium with $2 \mathrm{mg} / \mathrm{l} \mathrm{BAP}+1 \mathrm{mg} / \mathrm{l}$ kinetin $+1 \mathrm{mg} / \mathrm{l}$ NAA control (1) medium, as shoot length was $1.60 \mathrm{~cm}$ and $1.57 \mathrm{~cm}$, respectively. On the other hand, all explants cultured on medium supplemented with humic acid (powder) at $750 \mathrm{mg} / \mathrm{l}$ and humic acid (liquid ) at $0.75 \mathrm{ppm}$ humic acid (powder) at 250mg/l, respectively . Explants cultured on medium supplemented with humic acid (powder )at $750 \mathrm{mg} / \mathrm{l}$ and humic acid (liquid ) at $0.75 \mathrm{ppm}$ failed to form any shoots .The other treatments gave slightly lower leaf number per shoot compared with the optimum treatment.

\subsection{Rooting of in vitro shoots}

In vitro shoots from different treatments were separated and cultured on rooting media, which consist of MS basal medium with addition of different concentrations of natural components. Table (5) demonstrates the effect of coconut milk, 
Table (4): Effect of coconut milk, humic acid, orange juice and jojoba oil on shoot number, shoot length and leaf number of navel orange explants (After 8 weeks of culture ).

\begin{tabular}{|c|c|c|c|c|}
\hline Treatment & Concentration & Shoot number & Shoot length $(\mathrm{cm})$ & Leaves number \\
\hline Coconut milk \% & $\begin{array}{c}2.5 \\
5 \\
10 \\
\end{array}$ & $\begin{array}{c}3.17 \mathrm{def} \\
6.52 \mathrm{a} \\
6.07 \mathrm{ab} \\
\end{array}$ & $\begin{array}{c}0.90 \text { efg } \\
1.37 \text { c } \\
0.99 \text { ef } \\
\end{array}$ & $\begin{array}{c}2.23 \mathrm{cdef} \\
3.67 \mathrm{~b} \\
1.50 \mathrm{fg} \\
\end{array}$ \\
\hline \multirow{3}{*}{ Humic acid (powder) mg/l } & 250 & $4.62 \mathrm{c}$ & $1.33 \mathrm{c}$ & $3.10 \mathrm{bc}$ \\
\hline & 500 & $2.17 \mathrm{fg}$ & $0.77 \mathrm{~g}$ & $0.80 \mathrm{gh}$ \\
\hline & 750 & $0.00 \mathrm{~h}$ & $0.00 \mathrm{~h}$ & $0.00 \mathrm{~h}$ \\
\hline \multirow{3}{*}{ Humic acid (liquid) ppm } & 0.25 & $5.90 \mathrm{ab}$ & $1.30 \mathrm{c}$ & $2.67 \mathrm{cde}$ \\
\hline & 0.5 & $3.33 \mathrm{de}$ & $1.03 \mathrm{ef}$ & $1.50 \mathrm{fg}$ \\
\hline & 0.75 & $0.00 \mathrm{~h}$ & $0.00 \mathrm{~h}$ & $0.00 \mathrm{~h}$ \\
\hline \multirow{3}{*}{ Orange juice $\%$} & 5 & $4.17 \mathrm{~cd}$ & $1.07 \mathrm{de}$ & $1.43 \mathrm{fg}$ \\
\hline & 10 & $6.92 \mathrm{a}$ & $1.60 \mathrm{a}$ & $4.73 \mathrm{a}$ \\
\hline & 15 & $3.50 \mathrm{de}$ & $0.87 \mathrm{fg}$ & $1.40 \mathrm{fg}$ \\
\hline \multirow{3}{*}{ Jojoba oil \% } & 1 & $1.83 \mathrm{~g}$ & $1.40 \mathrm{bc}$ & $2.83 \mathrm{bcd}$ \\
\hline & 3 & $3.42 \mathrm{de}$ & $1.23 \mathrm{~cd}$ & 2.27 cdef \\
\hline & 6 & $1.40 \mathrm{~g}$ & $1.03 \mathrm{ef}$ & $1.70 \mathrm{efg}$ \\
\hline * Control (1) medium & & $5.08 \mathrm{bc}$ & $1.57 \mathrm{ab}$ & $5.40 \mathrm{a}$ \\
\hline$* *$ Control ( 2) medium & & $2.92 \mathrm{ef}$ & $1.23 \mathrm{~cd}$ & 1.87 def \\
\hline
\end{tabular}

Means designated with the same letter in the same column are not significantly different at L.S.D 0.05 level of probability

* MS basal medium with growth regulators $\quad * *$ MS basal medium without growth regulators

Table (5): Effect of coconut milk, humic acid, orange juice and jojoba oil on rooting formation of in vitro shoot explants navel orange explants( After 4 weeks of culture ).

\begin{tabular}{|l|c|c|c|}
\hline \multicolumn{1}{|c|}{ Treatment } & Roncentration & Root length (cm) \\
\hline & 2.5 & $1.70 \mathrm{hi}$ & $0.93 \mathrm{~cd}$ \\
Coconut milk \% & 5 & $4.87 \mathrm{e}$ & $1.60 \mathrm{a}$ \\
& 10 & $2.10 \mathrm{gh}$ & $1.10 \mathrm{~cd}$ \\
\hline & 250 & $6.13 \mathrm{~cd}$ & $1.53 \mathrm{a}$ \\
Humic acid (powder) mg/l & 500 & $7.00 \mathrm{~b}$ & $1.40 \mathrm{ab}$ \\
& 750 & $7.93 \mathrm{a}$ & $1.07 \mathrm{~cd}$ \\
\hline & 0.25 & $6.00 \mathrm{~cd}$ & $0.95 \mathrm{~cd}$ \\
Humic acid (liquid) ppm & 0.5 & $4.87 \mathrm{e}$ & $1.43 \mathrm{ab}$ \\
& 0.75 & $6.33 \mathrm{c}$ & $1.00 \mathrm{~cd}$ \\
Orange juice \% & 5 & $1.63 \mathrm{hi}$ & $0.93 \mathrm{~cd}$ \\
& 10 & $5.87 \mathrm{~cd}$ & $1.50 \mathrm{a}$ \\
\hline \multirow{2}{*}{ Jojoba oil \% } & 15 & $2.40 \mathrm{~g}$ & $0.60 \mathrm{e}$ \\
\hline *Control( 1) medium & 1 & $1.23 \mathrm{i}$ & $1.16 \mathrm{bc}$ \\
\hline **Control( 2)medium & 3 & $3.43 \mathrm{f}$ & $1.09 \mathrm{~cd}$ \\
\hline
\end{tabular}

Means designated with the same letter in the same column are not significantly different at L.S.D 0.05 level of probability

* MS basal medium with growth regulators $\quad * *$ MS basal medium without growth regulators 
humic acid, orange juice and jojoba oil on rooting of in vitro shoots. The highest percentage of rooting approximately 7.93 roots /shoot,was produced by adding humic acid (powder )at $750 \mathrm{mg} / 1$ to the culture medium followed significantly by the rooting percentage $(7.00 \%)$ of explants cultured on medium supplemented with humic acid (powder )at $500 \mathrm{mg} / \mathrm{l}$, while the lowest percentage of rooting was observed by adding jojoba oil at $1 \%$ to culture medium(1.23 roots/shoot). The rooting percentages of the other treatments were in between.

\subsubsection{Root length}

The results in Table (5) indicate that the longest roots observed by adding coconut milk at $5 \%$,humic acid (powder) at $250 \mathrm{mg} / 1,1 \mathrm{mg} / \mathrm{l} \mathrm{NAA}$ control (1) medium, orange juice at $10 \%$, humic acid (liquid) at $0.5 \mathrm{ppm}$ and humic acid (powder) at $500 \mathrm{mg} / \mathrm{l}$ to culture medium, $(1.60,1.53,1.50$, $1.50,1.43$ and $1.40 \mathrm{~cm}$ respectively) without significant differences between them. On the other hand, adding orange juice at $15 \%$ to culture medium resulted in the lowest root length $(0.60$ $\mathrm{cm}$ ). The root length of the other treatments was in between.

\section{DISCUSSION}

The work presented in this investigation provides a simple protocol for the micropropagation of navel orange using nodal explants from mature trees to investigate the effect of some natural materials on growth development of navel orange lateral buds. No contamination was observed from explants by using jojoba oil in culture medium at different concentrations. Using humic acid (powder or liquid ) in culture medium at different concentrations showed the lowest contamination percentage. while, using orange juice in the culture medium at different concentrations showed the highest contamination percentage. Nodes cultured on a medium with high concentrations of humic acid (powder or liquid ) can not able to form any shoots while, shoots can be easily derived from node cultures on medium containing other concentrations of humic acid (powder or liquid), coconut milk, orange juice and jojoba oil at different concentrations activation effects. All proliferated shoots can be easily rooted on rooting media consisted of different concentrations of natural materials activation effects .

These results are in agreement with many investigations where the initiation period of the shoot was significantly shortened in the presence of humic acid,and root initiation was significantly induced, especially when humic acid was used in a liquid medium with tropical crops ( Goenadi and Sudharama., 1995 ). Beside, humic acid increased the peroxidase activity in the in vitro culture of Carnation cv.Red charry (Corneanu et al., 2002 ) . Using a combination of potassein $\mathrm{N}(\mathrm{K}-\mathrm{N})$ as a foliar spray at $2 \mathrm{ml} / \mathrm{L}$ plus humic acid at $20 \mathrm{~mL}$ as a soil drench monthly improved vegetative growth and promoted the nutrients uptake of date palm cv. Sakkoty plantlets (Abdel-Galeil , 2010) .

In vitro growth of explant cultures from citrus cultivars was stimulated by addition of orange juice to a basal medium (Einest, 1978) .

Regarding culture establishment, the best results were achieved when $50 \mathrm{ml} / 1$ coconut water and $2.22 \mu \mathrm{M}$ BAP were added to the medium. For the in vitro multiplication stage the highest proliferation rates with an average of 3.4 new explants after 30 days were achieved with the coconut water concentration at $50 \mathrm{ml} / \mathrm{l}$ (Peixe et al., 2007 ) .

Jojoba oil ,Candida tennis and microelements mixture showed pronounced effect on bud sprouting and hastened the bud emerging on flame seedless grapevine (Abd El-Moity et al., 2006 ) .

\section{REFERENCES}

Abdel- Galeil L. M. (2010). Improving the growth of date palm cv. Sakkoty plantlets by some fertilization treatments. J.Biol. Chem. Environ. Sci.5(1):109-122.

Abd El-Moity T. H., Abd El-Zaher M. H. and Rabie A. M.(2006). Effect of some organic and biological treatments on flame seedless grapevine. Egypt. J. of Appl. Sci. 21 (8B),581-620.

Agriculture statistics (2007). Ministry of Agriculture, Egypt .

Al- Bahrany A.M. (2002). Effect of phytohormones on in vitro shoot multiplication and rooting of lime Citrus aurantifolia (christm) Swing Scientia Horticulturae 95:285-295.

Al-Kayri J.M. and Al-Baharany A. M..(1982). In vitro micropropagation of Citrus aurantifolia (lime). Current Science, 81, 9,10) 1242-1246.

Barlass M. and Skene K.G.M.(1982). In vitro plantlet formation from citrus species and hybrids . Scientia Hort. 17: 333-341 .

Corneanu M., Marinescu G., Babeanu C., Badea E., Atyim P. and Corneanu G. C.(2002). Humic acid action on some physiological processes in carnation grown in vitro. Buletinul- Unversitatii- de- Stiinte- Agricole- 
Si- Medicina- Veterinara- Cluj- NapocaSeria- Horticultura. 57: 49-52.

De Pasquale F., Carimi F. and Crescimanno F.G.(1994). Somatic embryogenesis from styles of different cultivars of Citrus Limon (L.) Burm. Aust.J. Bot. 42:587-594.

Einset J. W.(1978).Stimulation of fruit explant cultures with orange juice. Plant Physoil. 62:885-888.

Goenadi D. H. and Sudharama I. M.(1995). Shoot initiation by humic acids of selected tropical crops grown in tissue culture. Plant Cell Reports 15:59-62.

Moore G.A.(1986). In vitro propagation of citrus rootstocks. Hort. Science, 21:300-301.

Murashige T. and Skoog F. (1962). A revised medium for growth and bioassay with tobacco tissue cultures. Physiol. Plant.,15: 473-497.

Peixe A., Raposo A., Lourenco R., Cardoso H. and Macedo E. (2007).Coconut water and
BAP successfully replaced zeatin in olive micropropagation. Scientia Horticulturae 113: 1-7.

Roistacher C.N., Navarro L. and Murashige T.(1976).Recovery of citrus selections free of several viruses, exocortis viroid and spiroplasma citri by shoot-tip grafting in vitro.Proc.7.Conf.Int.OrganizationVirol.,IOC V, Riverside, 186-193.

Sauton A., Mouras A. and Lutz A.(1982). Plant regeneration from citrus root meristems. $\mathrm{J}$. Hortic. Sci., 57:227-231.

Snedecor G. W. and Cochran W. G.(1980). Statistical Methods. Oxford and J. B. H. Publishing Com. $6^{\text {th }}$ edition .

Vardi A., Spiegel-Roy P. and Glaun E.(1982). Plant regeneration from citrus protoplasts : Variability in methodological requirements among cultivars and species. Theor. Appl. Genet, 62:171-176.

$$
\text { رثأثير إضافة بعض المواد الطبيعية على مراحل الإكثار الاقيق للبرتقال أبو سرة معملياُ }
$$

$$
\begin{aligned}
& \text { ملخص }
\end{aligned}
$$





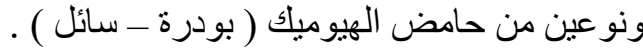

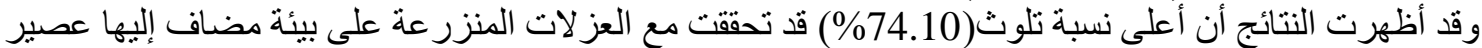

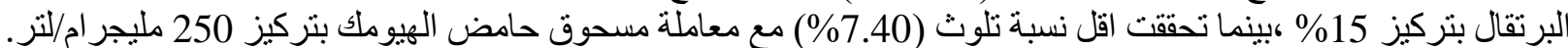

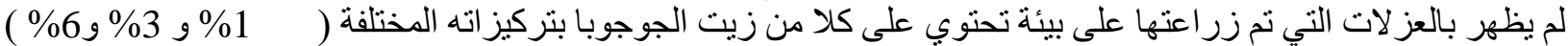$$
\text { بجانت الكنترول (1) ( 2مليجر ام /لتر 6-بنزيل امينو بيورين + 1مليجر ام كينيتين + 1مليجر ام نفتالين حامض الخليك) لم يظهر }
$$

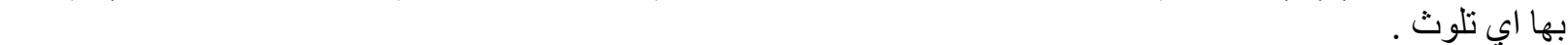

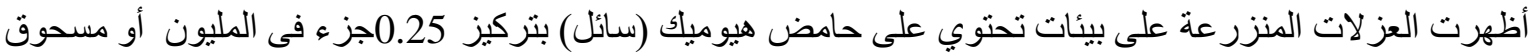

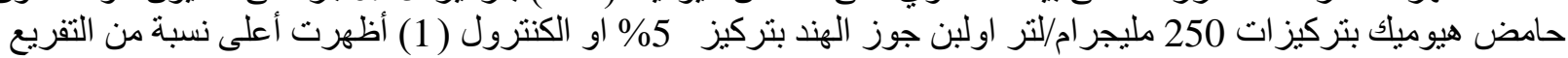



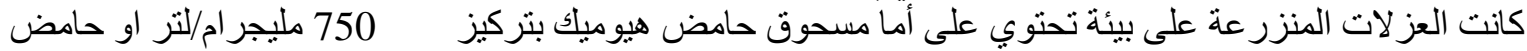

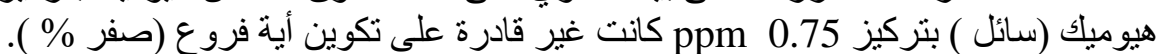

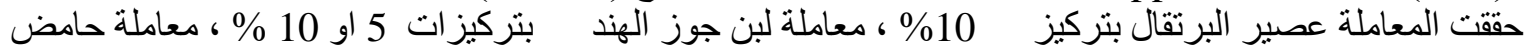

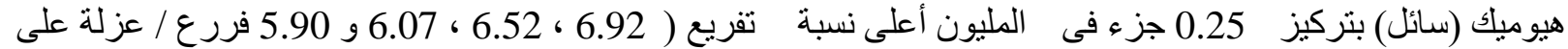



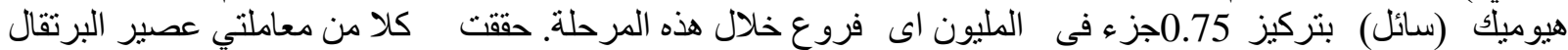

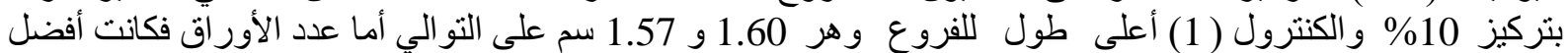




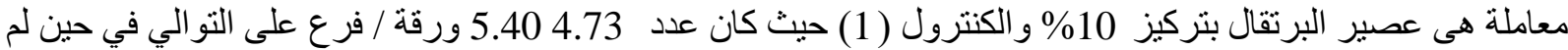

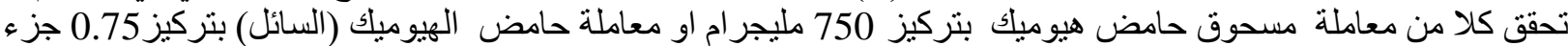



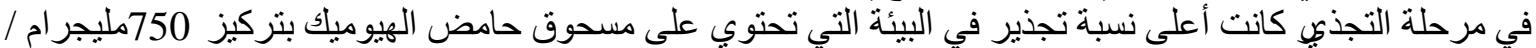

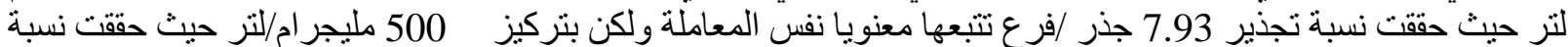

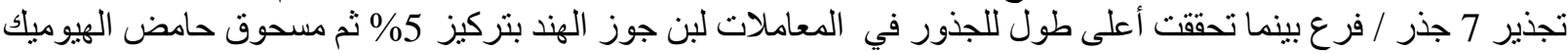



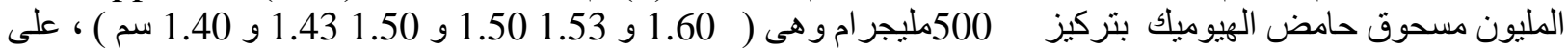
التوالي .

المجلة العلمية لكلية الزراعة - جامعة القاهرة - المجلد (61) العدد الرابع (أكتوبر 2010):422-429. 